\title{
The UN System for Environmental-Economic Accounts for Water (SEEA-W) and groundwater management: the experience of the Arno River Basin Authority within the PAWA project
}

\section{II sistema di water accounting delle Nazioni Unite (SEEA-W) e la gestione delle acque sotterranee: l'esperienza dell'Autorità di Bacino del Fiume Arno nel progetto europeo PAWA}

Bernardo Mazzanti, Isabella Bonamini, Gaia Checcucci, Lucia Fiumi, Francesco Consumi, Stefano Bartalesi, Giovanni Montini

Riassunto: Il progetto PAWA (Pilot Arno Water Account), recentemente finanziato all'interno del bando della Divisione Ambiente della Commissione Europea "Preparatory Action on development of prevention activities to halt desertification in Europe", vede impegnati ISPRA, Autorità di Bacino del Fiume Arno e l'organismo internazionale SEMIDE/EMWIS in un'iniziativa pilota finalizzata alla gestione della scarsità idrica e della siccità nell'area del bacino dell'Arno. In tale area, caratterizzata da un forte impatto di tali fenomeni e da rilevante sfruttamento delle risorse, l'Autorità di bacino dell'Arno ha maturato una significativa esperienza nella definizione del bilancio idrico e nello sviluppo di applicazioni sperimentali nell'ambito delle attività dei gruppi di esperti della Commissione Europea in materia di scarsità idrica e siccità, in particolare nel più recente periodo di programmazione della Common Implementation Strategy della Direttiva Acque (2000/60/CE). Con questo progetto si vuole ulteriormente sviluppare questa esperienza applicando il sistema di contabilità idrica delle Nazioni Unite denominato System of Enviornmental Economic Accounts for Water, con lo scopo finale

\section{Parole chiave: gestione acque sotterranee, contabilità idrica am- bientale, Bacino del Fiume Arno, acquifero, bilancio idrico.}

Keywords: groundwater management, environmental water accounts, Arno River Basin, aquifer, water balance.

Bernardo MAZZANTI 莑"

Isabella BONAMINI

Gaia CHECCUCCI

Lucia FIUMI

Francesco CONSUMI

Stefano BARTALESI

Giovanni MONTINI

Autorità di Bacino del Fiume Arno

Via dei Servi 15, Firenze.

Tel. +39055 26743246, Fax +3905526743250

b.mazzanti@adbarno.it

Ricevuto: 28 giugno 2014 / Accettato: 09 settembre 2014

Pubblicato online: 30 settembre 2014

(C) Associazione Acque Sotterranee 2014 di ottimizzare le misure per contrastare i casi di scarsità di idrica attraverso la definizione di diversi scenari di intervento.

L'obiettivo è quello di produrre entro marzo 2015 l'applicazione delle tabelle di contabilità idrica previste dal sistema su base mensile, per il periodo 1999-2013, usando i migliori dati disponibili rilevati da misure sul campo o stimati da modelli, quando necessario. È prevista una valutazione della qualità dei sei di dati utilizzati; tavole, mappe e grafici verranno prodotte a comporre l'output dell'applicazione del sistema, in cooperazione anche con i fornitori dei dati e con i portatori di interesse, che verranno coinvolti in vari workshop. $\mathrm{E}$ infine verranno messe a fuoco le misure più opportune per il contrasto alla scarsità idrica, da includere nel Piano di gestione delle Acque, in accordo con la Direttiva Europea 2000/60/CE.

Abstract: The Pilot Arno Water Accounts (PAWA) project was recently funded under the Call "Preparatory Action on Development of Prevention Activities to Halt Desertification in Europe" of the Directorate-General for the Environment of the European Commission to promote preventive actions to manage water scarcity and drought phenomena and to meet one of the main goals under European environmental legislation: the effective and sustainable management of water resources. The partners involved in the implementation of the PAWA project (IS PRA, Arno River Basin Authority, SEMIDE/EMWIS) will carry out a pilot initiative in the Arno River Basin, an area severely affected by water scarcity and droughts phenomena and characterized by water withdrawals and land use changes. In the area a large experience about water balance application was already performed, for example in the context of the Water Framework Directive Common Implementation Strategy. Moving from this knowledge, the objective of the project is the definition of water accounting processing based on the UN System of Environmental Economic Accounts for Water, with the final goal to optimize a list of effective measures to face water scarcity phenomena. By the end of project (March 2015) the PAWA partnership aims at preparing physical water stock accounts, using the best available data resulting from field measurements or models, on a montbly step for the period 1999-201. The quality of each dataset will be assessed; tables, maps and graphs will be produced as outputs of the projects in cooperation with local stakeholders and players of the water sector. Furthermore, water accounts will be used to assess the potential impact of various measures related to water resource efficient exploitation in the most vulnerable sub-basins; their tolerability will be tested during workshops with stakeholders. Finally, water efficiency targets for potential future integration into Arno River Basin Management Plan will be identified 


\section{Introduction}

The System of Environmental Economic Accounts was set up to intertwine economic and environmental data. Basically, it is a transposition of the System of National Accounts into the environmental system. Its sub-system for Water (SEEAW) was adopted by the United Nations Statistical Division in 2007 as an international statistical standard (UNSD 2007, 2012). SEEA-W has developed a common and shared methodology for water accounts. On this basis, in August 2009 the European Commission adopted the Communication "GDP General Defense Plan - and beyond - measuring progress in a changing world" (European Commission, 2009): a roadmap to deal with the need for standardized environmental accounting and its possible contribution to sustainable development.

The pilot application of the SEEA-W standards to basins located in the Mediterranean area is part of a wider European Commission project to develop water balances at European level using the SEEA-W methodology (European Environment Agency 2013) and to support the European Commission communication "A Blueprint to Safeguard Europe's Water Resources" (European Commission, 2012), whose ambitious goal is to review water scarcity and drought management policy in the European Union, highlighting the areas for further action. In fact, in 2007 the Commission carried out an assessment of water scarcity and drought events in the European Union and presented a set of policy options to increase water efficiency and water savings in the Communication "Addressing the challenge of water scarcity and droughts in the European Union" (European Commission, 2007). The review of this policy options revealed gaps in the implementation of adequate policies in the Member States pointing out the need of further improvements (European Commission 2012; European Commission - DG Environment 2012).

In this context, the presented pilot application is primarily aimed at supplying bottom-up experiences to evaluate the "replicability" of these methodologies at the wider European scale.

Specifically, SEEA- W "focuses on the interaction between water resources and the economy where the economy is the system that abstracts water for consumption and production activities and puts in place the infrastructure to mobilize store, treat, distribute and return water to the environment" (European Environment Agency 2013). The procedure aims at preparing water flow diagrams, called "Physical Supply and Use Tables", taking into account inflows/outflows from the environment into the economy and vice versa (Fig. 1, Fig. 2).

Of particular relevance in the water accounting method is "the model that describes inland water resources system in terms of stocks and flows; it provides information on the stocks of water resources at the beginning and end of the accounting period and the changes herein. These changes are described in terms of flows brought about by the economy and by natural processes" (European Environment Agency 2013).

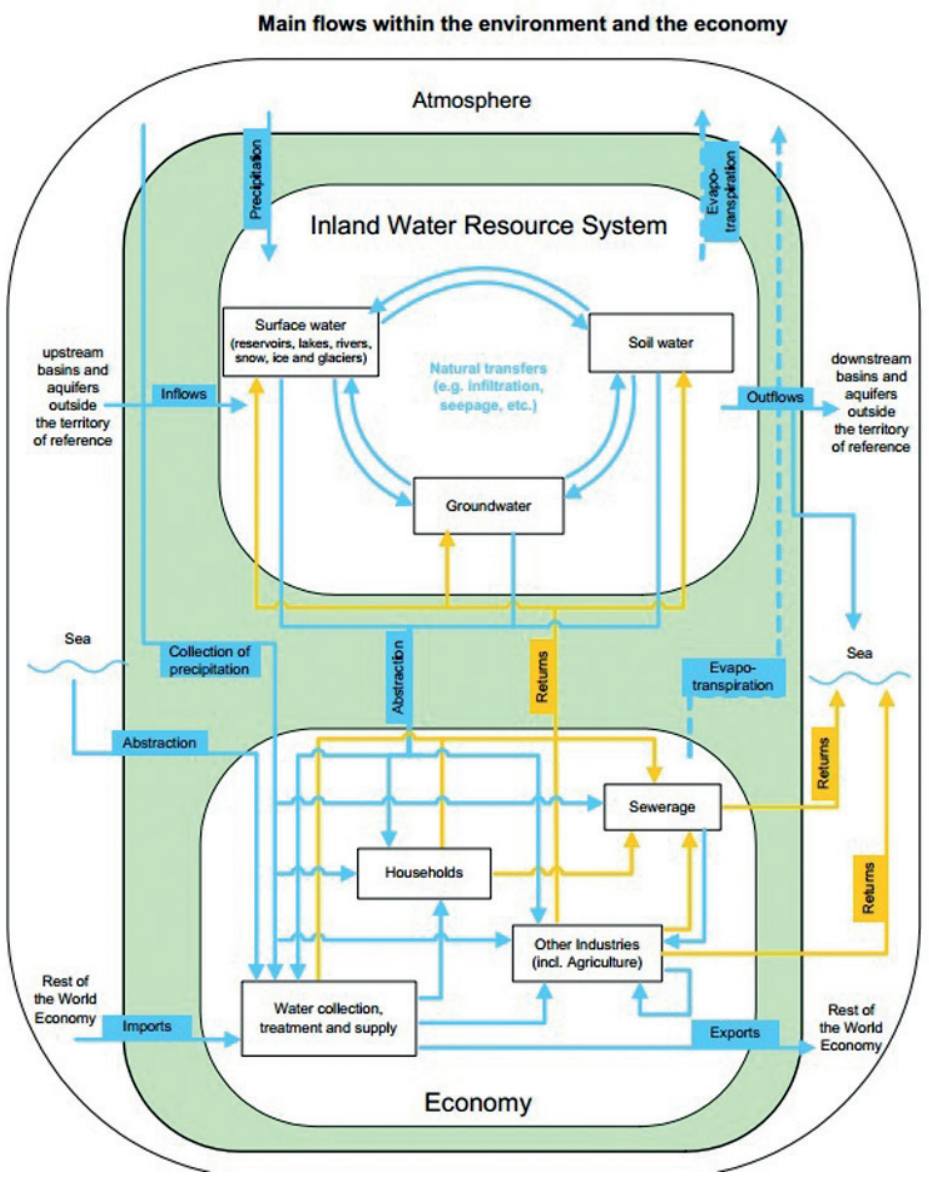

Fig. 1 - Main flows within the inland water resource system and the economy SEEAW (EEA, 2009).

Fig. 1 - Flussi principali per il sistema di risorse idriche e asset economici delle acque interne nel sistema SEEAW (EEA, 2009). 
A. Physical use table (physicalunits)

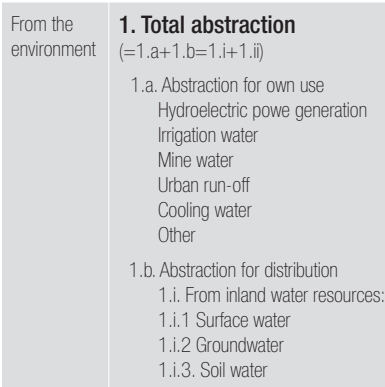

Fig. 2 - Detail of Physical use table, with the reference to ISIC (International Standard Industrial Classification) codes for industries.

Fig. 2 - Dettaglio della tabella relativa agli usi fisici, con il riferimento alle categorie ISIC (International Standard Industrial Classification) delle attività industriali.

\section{Project Plan}

The project plan, developed by the Italian Institute for Environmental Protection and Research (ISPRA - leading partner), the Arno River Basin Authority and the International Organization SEMIDE/EMWIS (Systemé Euro-Mediterranéen di Information sur le savoir-fair dans le Domaine de l'Eau/Euro-Mediterranean Information System on knowhow in the Water Sector), which is an initiative of the EuroMediterranean Partnership (EuroMed) for information and knowledge sharing in the water sector among the EuroMed countries, is divided into the following activities:

- a kick-off activity to identify the pilot case areas and an inventory draft of the existing datasets with the involvement of local stakeholders;

- data collection, aimed at preparing a metadata catalogue (this activity implies the validation and description of existing datasets, their availability, quality, reliability);

- preparation of physical water accounts following the framework provided by the SEEA-W, using the best available data resulting from field measurements or numerical models. These water accounts will be calculated at a monthly scale for the period 1999-2013 in order to identify trends. The quality of each dataset will be assessed using a scorecard based on the estimated accuracy of the data source;

- graphical representations (including maps), based on the water accounts, aimed at decision making and concertation with local stakeholders within the basin, and in agreement with the international standards applied to spatial data infrastructures;

- use of the water accounts to assess the potential impact of combining various measures related to water resource efficiency in the most vulnerable sub-basins and to evaluate their acceptability by stakeholders;

- detection of water efficiency targets for potential future integration into the Northern Apennines River Basin Management Plan;
- dissemination of the project results and experiences sharing with other basin organizations and water authorities in Italy, Europe and Mediterranean areas.

\section{Data Collection and Validation}

The baseline scenario for the project implementation is based on the availability of water balance data at basin scale and on the existence of an approved water balance plan, whose data have been gathered, validated and processed at basin and sub-basin scale and for each specific groundwater body. The most significant achievements of the Arno River Basin technical staff have been the acquisition of an extensive experience in data processing and modeling and the development of a high capacity to collect, analyze, validate and store data. The project starting point has been the drafting of an inventory of all datasets and sources at sub-basin level. Three specific areas have been identified on the basis of their vulnerability to water scarcity and drought, main pressures on water resources, existence of different water uses and information availability (Fig. 3).

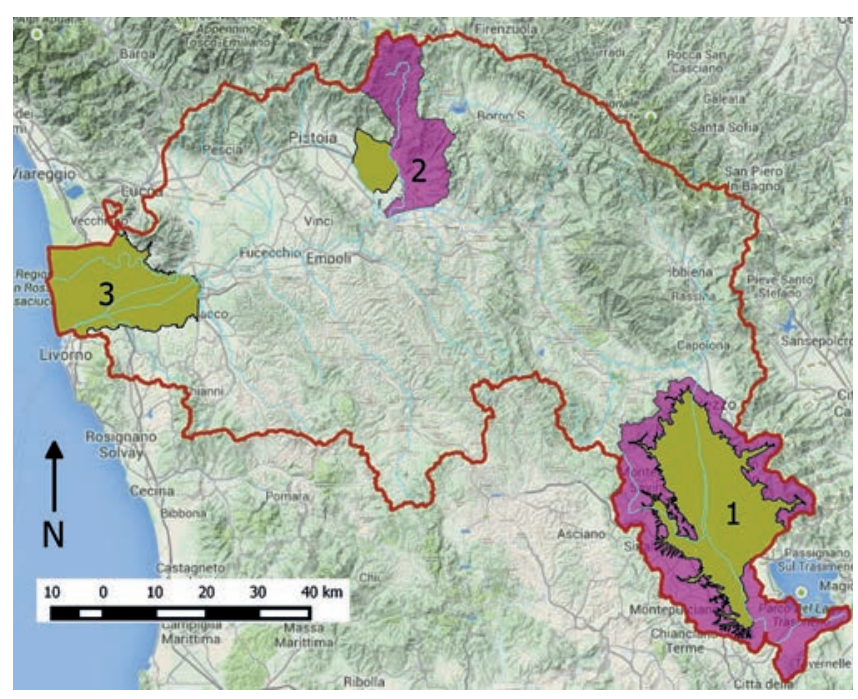

Fig. 3 - Selected areas for procedure application: (1) Valdichiana, (2) Val di Bisenzio and Prato floodplain aquifer, (3) Pisa aquifer. In brown the studied groundwater bodies, in purple surface water basins.

Fig. 3 - Aree selezionate per l'applicazione della procedura: (1) Valdichiana, (2) Val di Bisenzio e acquifero della Piana di Prato, (3) acquifero di Pisa. Sulla mappa le acque sotterranee analizzate sono rappresentate in marrone, $\mathrm{i}$ bacini idrografici in viola

The availability of the national datasets of ISPRA (Istituto Superiore per la Protezione e la Ricerca Ambientale, Institute for Environmental Protection and Research) and the direct involvement of ISTAT (Istituto Nazionale di Statistica, Italian National Institute of Statistics) have ensured the supply of useful data at national level. The broad consultation process involving local stakeholders has provided a realistic and helpful feedback.

Local data providers and producers have been invited to collect the existing data sources relevant to the compilation of the SEEA-W tables. The description of the collected datasets have been entered in a metadata Geonetwork catalogue 
populated with more than 100 data sources. The experience of EMWIS has been particularly important to check the INSPIRE Directive compliance of the metadata catalogue (European Parliament, 2007).

The existing datasets have been matched with the SEEA-W required data structure that prescribes the monthly temporal resolution and the geographical sub-basin scale.

Data quality has been assessed: temporal datasets have been validated, aggregated or estimated, whereas local geographical units have been matched with the Functional Elementary Catchments (FECs) developed by the ECRINS (European Catchments and Rivers Network System) European Platform (European Environment Agency 2012). ECRINS is a composite geographical system developed by the Joint Research Center of the European Commission, organized in a layer of 181,071 "functional elementary catchments (FECs)" whose average size is about 62 square $\mathrm{km}$. Particular attention has been paid to ensure that geographical units used for water resources availability matched with geographical units used for water abstraction and economic activities.

\section{Focus on groundwater management}

Regarding the application of the tested methodology (SEEA-W), three aquifers are being thoroughly investigated: Pisa area, Prato floodplain and Chiana valley. The detailed analysis of abstraction sources is of particular relevance to the water accounting method. The SEEA-W methodology requires that groundwater exchanges with soil and rivers are analyzed in terms of inflows/outflows from soil to groundwater and inflows/outflows from groundwater to rivers. Accord- ing to this approach, the data collection activity has been focused on a detailed review of abstraction points based on their typology and characteristics, splitting the dataset between wells directly tapping the aquifer storage and wells abstracting water from the riverbank filtration zone. An example of their different spatial distribution and density is provided in figure 4.

The complexity of the project is well exemplified by the number of records of the withdrawals dataset. Groundwater management data, gathered until June 2014, are more than 100,000. They are characterized by an extremely broad distribution of the associated abstracted quantities (see Fig. 5) and

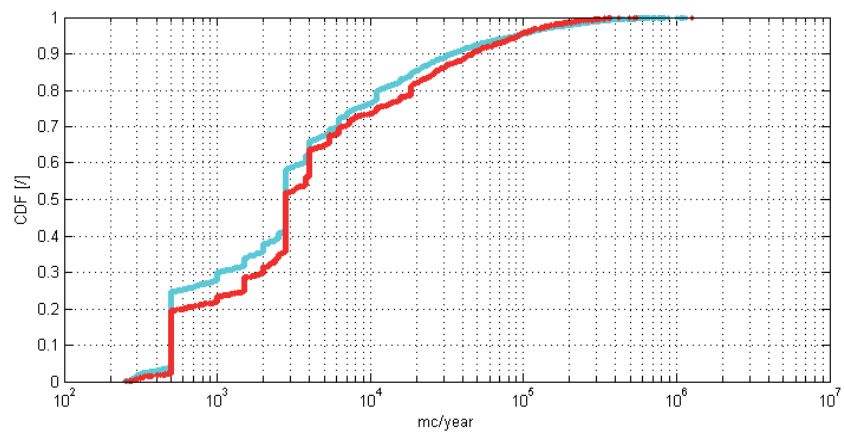

Fig. 5 - Cumulative Distribution Function (CDF - plotting position method) of groundwater withdrawals ( $\mathrm{m}^{3} /$ year). In red, withdrawals wells tapping the riverbank. filtration zone.

Fig. 5 - Funzione di distribuzione cumulata, rappresentata tramite il metodo della plotting position, dei prelievi da acque sotterranee ( $\left.\mathrm{m}^{3} / \mathrm{anno}\right)$. In rosso, prelievi dalla risorsa idrica di subalveo.

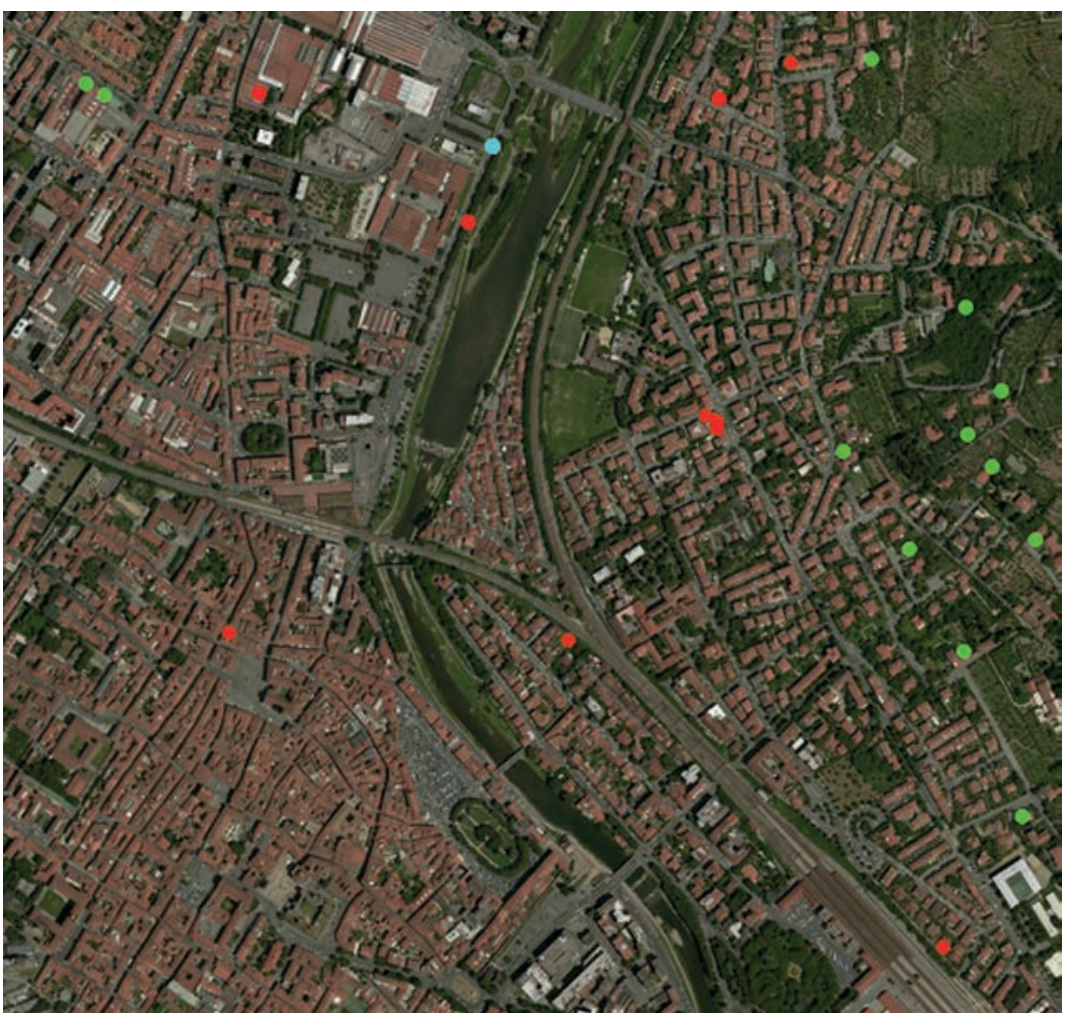

Fig. 4 - . Location of wells and superficial withdrawals along the Bisenzio river. In red, wells tapping the riverbank filtration zone; in green, withdrawals from the deeper aquifer layers. The cyan point is the only superficial abstraction along the selected river reach.

Fig. 4 - Distribuzione spaziale dei pozzi e dei prelievi superficiali lungo il fiume Bisenzio. In rosso, i pozzi di subalveo; in verde, gli approvvigionamenti dagli strati più bassi dell'acquifero. Il punto celeste rappresenta l'unico prelievo superficiale nel tratto selezionato. 
significant seasonal fluctuations, according to their different uses (i.e. manufacturing typology, irrigation demand, human demand and related population fluctuations).

\section{The results of PAWA will be used}

The results of PAWA will be use:

- at Arno river basin scale, by Arno River Basin Authority and local stakeholders to improve decision making related to quantitative water resources management;

- at the Italian level, by ISPRA for coherent developments in other river basins in order to face water scarcity, drought and/or desertification in the future, according to european guidelines (European Commission 2012);

- at the EuroMed level, by EMWIS in particular in the framework of the Shared Environmental Information System to South EU neighborhood countries to enhance water information systems;

- at the EU level, by the EEA and DG ENV for the Common Implementation Strategy (CIS) required by the EU Water Framework Directive (WFD 2000/60/EC) to improve the EU wide water accounts and to provide examples of quantitative water resources management measures and related targets that could be added to RBMPs as a response to the outcomes of the "Blueprint to safeguard Europe's waters".

The completion of the SEEA-W tables will help the Arno River Basin Authority to identify the most suitable and effective measures to face water scarcity and drought issues to be included in the River Basin Management Plan update (required by the end of 2015) together with the new water efficiency detected targets. The optimization of these measures is one of the expected results of the project, whose outcomes will be further disseminated by ISPRA at national level and by EMWIS in the Mediterranean area.

\section{REFERENCES}

European Commission (2007). Addressing the challenge of water scarcity and droughts in the European Union. Report COM (2007) 44.

European Commission (2009). GDP - General Defense Plan - and beyond - measuring progress in a changing world. Report COM (2009) 433

European Commission (2012a). A Blueprint for Safeguard Europe's Water Resources. Report COM (2012) 673.

European Commission (2012b). Communication from the Commission to the European Parliament, the Council, the European Economic and Social Committee and the Committee of the Regions. Report on the Review of the European Water Scarcity and Droughts Policy. SWD(2012) 380 final.

European Commission - Directorate General Environment (2012) Preparatory Action - Development of Prevention Activities to halt desertification in Europe - Service Contract to contribute to the building of Water and Ecosystem accounts at EU level. Final Report

European Environment Agency (2009). Water resources across Europe - confronting water scarcity and drought, EEA Report No 2/2009

European Environment Agency (2012). EEA Catchments and Rivers Network System - ECRINS v1.1. Rationales, building and improving for widening uses to Water Accounts and WISE applications, EEA Technical Report No 7/2012.

European Environment Agency (2013). Results and lessons from Implementing the Water Assets Accounts in the EEA Area. Technical Report No 7/2013.

European Parliament (2007). Directive 2007/2/EC of the European Parliament and of the Council of 14 March 2007 establishing an Infrastructure for Spatial Information in the European Community (INSPIRE) 14.03.2007.

UNSD (2007). Environmental accounting: System of EnvironmentalEconomic Accounting for Water (Statistical Commission Background document). United Nations Statistics Division, UNSD Thirty-eighth session 27 February - 2 March, New York

UNSD (2012). SEEA-Water System of Environmental-Economic Accounting for Water. Publication of Department of Economic and Social Affairs. Statistics Division. 